DOI https://doi.org/10.18551/rjoas.2021-01.06

\title{
RELATIONSHIP PERSON - ORGANIZATION FIT AND WORKLOAD TO WORK STRESS AND JOB SATISFACTION
}

\author{
Sanjiwani Putu Ari Pertiwi, Riana I Gede ${ }^{\star}$, Surya Ida Bagus Ketut \\ Master's Program of Management, Faculty of Economics and Business, \\ University of Udayana, Indonesia \\ *E-mail: gederiana@unud.ac.id
}

\begin{abstract}
Employees have an important role in the organization to perform its functions and achieve organizational objectives. Managing employees is not an easy thing because the organization involves various stakeholders, including leaders and systems. Organizations must pay attention to good relations between these various elements to create a good working atmosphere and employee job satisfaction. The purpose of this study was to analyze the effect of person-organization fit and workload on job stress and job satisfaction.
\end{abstract}

\section{KEY WORDS}

Job satisfaction, person-organization fit, job stress, workload.

Job satisfaction is a person's perspective, both positive and negative about their work (Shurbagi, 2014). Job satisfaction refers to feelings or states of mind according to the nature of work (lqbal, 2012). Job satisfaction is very important because basically, employees have different levels of satisfaction. After all, satisfaction is individual and by the characteristics that apply to him. Job satisfaction is a condition for employees who are satisfied with work (Yasa, 2019). Person-organization fit is needed in maintaining the continuity of employees in an organization, if employees do not feel the alignment between the values adopted by the organization are likely to feel uncomfortable and cause dissatisfaction at work (Kristof, 1996). Employees have a subjective assessment of the characteristics they have with the jobs offered by the organization in the process of job selection and acceptance (Charles, 2005). The assignments that are later given are under the values held by employees and the organization affects the increasing job satisfaction of employees (lqbal, 2012).

The workload is a set of activities that must be completed by employees in an organizational unit (Bazazan et al., 2019). The workload is the volume of work done by employees and can be in the form of physical workload and mental workload. The physical workload is a workload that can be seen by the naked eye such as fatigue treatment can stir a hat. The results of the treatment can be felt immediately. The mental workload can affect employee behavior, making it more difficult to cope with. Too much workload can cause employee behavior deviations. Further work stress is cognitive-behavioral and emotional patterns of psychological reactions to adverse and dangerous aspects of each job and the organization (Velnampy and Aravinthan, 2013). Job stress can affect the ability of employees to face work which in turn can hinder performance achievement so that it can harm the organization (Deng et al., 2019). Work stress not only attacks employees in the field but also attacks superiors behind the table. Handling employee work stress must be managed properly to enable employees to achieve organizational goals. This study aims to analyze the effect of workload and person organizational fit on workload and job satisfaction.

\section{LITERATURE REVIEW}

The workload is the average activity frequency of each job within a certain period (Kokoroko \& Sanda, 2019). Too much workload can cause tension, causing stress (Vignato et al., 2020). Nursing personnel who have a high workload tend to have a low level of satisfaction, while nursing personnel who have moderate levels of satisfaction have higher levels of satisfaction (Rochmah and Nurul, 2013). The goals of an organization can be 
fulfilled when employees respect the values of the organization and strive to fulfill its primary goals. Person-organization fit can help employees build a long-term relationship with the organization, where they tend to show behaviors that have a positive impact on organizations (Amarneh \& Muthuveloo. 2020). Person-organization fit is a determining indicator for generation $Y$ employee job satisfaction in the Indonesian banking industry (Liu et al., 2010). The level of conformity between employees and the organization has a significant influence and has an important role in employee job satisfaction.

$\mathrm{H} 1$ : Workload has a significant negative effect on job satisfaction.

$\mathrm{H} 2$ : Person-organization fit has a significant positive effect on job satisfaction.

Job stress has a negative relationship with employee job satisfaction. Low job satisfaction can lead to stress when employees feel the workload, Mansoor et al., 2011), states that employees who are not ideal satisfied with the work showed a negative attitude towards work and will feel stress on the job. Physical or psychological stress is a state of distress experienced by individuals facing extraordinary demands and obstacles in their work (Hans et al., 2014). The workload given to nurses must be adjusted to their capacity. If the amount of workload given exceeds the capacity of nurses, of course, it will reduce the work productivity of nurses because in carrying out their duties, nurses will feel tired. Too little workload can also affect a person's psychological well-being. Workload also causes significantly more stress on primary school teachers than preschool and secondary teachers, and preparation of secondary school teachers at the start of the school year (Al-Mohannadi and Capel, 2007). The match or similarity that occurs between individuals and organizations has been obtained since the recruitment of employees is carried out because applicants see first, the organization is suitable or not with the character of the prospective employee (Jutras \& Mathieu, 2016). Person-organization fit can occur when there are fundamental characteristics that match or match the characteristics of the organization where the individual works so that employees do not feel pressured while working (Kim et al, 2013).

H3: Job stress has a significant negative effect on job satisfaction.

$\mathrm{H} 4$ : Workload has a significant positive effect on work stress.

H5: person-organization Fit has a significant negative effect on Job Stress.

Workload if associated with work stress will have an impact on employee job satisfaction. Workload has a positive effect on work stress; Job stress hurts job satisfaction. This means that the higher the workload, the higher the level of work stress, and this affects decreasing job satisfaction. Job stress has a mediating effect in the relationship between workload and job satisfaction. This shows that the increasing work stress will be able to mediate the relationship between workload and employee job satisfaction will decrease (Inegbedion et al., 2020). Person organization fit when associated with work stress can have an impact on employee satisfaction. Stress has an impact on the relationship between satisfaction and organizational person fit in an organization (Chen and Cary, 2016).

H6: Job stress mediates the effect of workload on job satisfaction.

$\mathrm{H7}$ : Job stress mediates the influence of Person organization on job satisfaction.

\section{METHODS OF RESEARCH}

This research was conducted at Ari Canti Hospital with a population of all nurses totaling 135 people. Determination of the sample was done using a simple random sampling technique. The results of the calculation obtained a sample size of 101 nurses. Quantitative and qualitative data, both from primary and secondary sources, were collected by conducting interviews and distributing questionnaires. The questionnaire was prepared based on workload variables, person-organization fit, job stress, and job satisfaction with several question items. The workload variable adopted Parimita et al, (2017), the personorganization fit variable adopted the research of Netemeyer et al (1997), the work stress variable adopted research by Taylor (1991), and the job satisfaction variable adopted the research of Weiss, et al. (1967). Before the data was collected as a whole, the data validity was tested on 30 samples. An instrument is said to be valid if the value in its correlation is ( $r$ ) $\geq 0.30$ (Rahyuda, 2017). Furthermore, the collected data were analyzed using Smart PLS. 


\section{RESULTS OF STUDY}

Model evaluation is done by looking at the value of outer loading each - each indicator and variable I workload, person-organization Fit, Job Stress, and Job satisfaction with the provisions of the loading value of not less than 0,50 , and t-statistic values above 1.96. Based on Table 1, it can be seen that all indicators in the workload variable, person-organization Fit, Job Stress, and Job Satisfaction have an outer loading of more than 0.70 . Workload (X1), the Work Standard indicator (X1.3) is the strongest measure with an outer loading value of 0.936. The Equation of Fairness Value (X2.4) on the person-organization fit (X2) variable is the strongest measure for this variable with an outer loading value of 0.936 . In the work stress variable (Y2), the stress indicator of emotional response (Y2.3) has the highest outer loading value of 0.945 . Then for the Job Satisfaction variable (Y1), the extrinsic satisfaction indicator (Y1.2) obtained the highest outer loading value, namely 0.962 .

Table 1 - Outer Loading Research Variables

\begin{tabular}{|c|c|c|c|c|c|c|}
\hline Indicator & Workload (X1) & Person Organization Fit (X2) & Job Stress (Y2) & Job satisfaction (Y1) & T Statistics & $\mathrm{P}$ Values \\
\hline $\mathrm{X} 1.1$ & 0.909 & & & & 59,722 & 0,000 \\
\hline $\mathrm{X} 1.2$ & 0.921 & & & & 61,364 & 0,000 \\
\hline $\mathrm{X} 1.3$ & 0.936 & & & & 62,238 & 0,000 \\
\hline X2.1 & & 0.886 & & & 35,476 & 0,000 \\
\hline X2.2 & & 0.927 & & & 57,315 & 0,000 \\
\hline X2..3 & & 0.933 & & & 55,086 & 0,000 \\
\hline X2.4 & & 0.936 & & & 77,112 & 0,000 \\
\hline Y2.1 & & & 0.866 & & 26,889 & 0,000 \\
\hline Y2.2 & & & 0.900 & & 54,655 & 0,000 \\
\hline Y2.3 & & & 0.945 & & 87,269 & 0,000 \\
\hline Y2.4 & & & 0.924 & & 61,172 & 0,000 \\
\hline Y1.1 & & & & 0.944 & 93,202 & 0,000 \\
\hline Y1.2 & & & & 0.962 & 120,576 & 0,000 \\
\hline Y1.3 & & & & 0.957 & 103,035 & 0,000 \\
\hline
\end{tabular}

Table 1 presents each workload variable, person-organization Fit, Job Stress, and Job Satisfaction with an Average Variance Extracted (AVE) value of more than 0.5. Based on the test results, it can be concluded that all indicators are valid and feasible indicators to measure their respective variables.

Discriminant validity uses the measurement of cross loading values for all indicators. The value of cross-loading on all indicators is expected to have the highest value on the measurement of their respective variables. The cross-loading value is presented in Table 3 showing that all variable indicators have a cross-loading value of more than 0.50 , it can be said that the variable meets the requirements for discriminant validity.

Table 2 shows the value of each square root of the Average Variance Extracted (AVE) and the correlation between variables. It is explained that the value of the square root of the Average Variance Extracted (AVE) for each variable has a higher value than the correlation between variables. From the comparison of the square root of the Average Variance Extracted (AVE) to the correlation value between variables, it can be said that the evaluation of the measurement model has a good discriminant validity value.

Table 2 - Comparison of the Square Roots of AVE and Correlations Between Variables

\begin{tabular}{lllllll}
\hline Research variable & AVE & VAVE & Workload (X1) & Person Organization Fit ( X2) & Job Stress (Y2) & Job Satisfaction (Y1) \\
\hline BK (X1) & 0.851 & 0.922 & 1,000 & $-0,733$ & 0.755 & $-0,814$ \\
POF (X2) & 0.847 & 0.920 & $-0,733$ & 1,000 & $-0,801$ & 0.832 \\
SK (Y2) & 0.827 & 0.909 & 0.755 & $-0,801$ & 1,000 & $-0,899$ \\
KK (Y1) & 0.911 & 0.954 & $-0,814$ & 0.832 & $-0,899$ & 1,000 \\
\hline
\end{tabular}

The construct reliability of a measurement model on a reflective indicator can be seen using the composite reliability value and the value of Cronbach's Alpha. The results of the measurement model reliability test are presented in the Table. 3. Based on the value of composite reliability and Cronbach's Alpha, each variable obtains measurement results with a value above 0.70 . Thus, the measurement model has good reliability. 
Table 3 - Value of Composite Reliability

\begin{tabular}{llll}
\hline Variable & Cronbach's Alpha & Composite Reliability & Result. \\
\hline Workload (X1) & 0.912 & 0.945 & Reliable \\
Person Organization Fit (X2) & 0.940 & 0.957 & Reliable \\
Job Stress (Y2) & 0.930 & 0.950 & Reliable \\
Job Satisfaction (Y1) & 0.951 & 0.968 & Reliable \\
\hline
\end{tabular}

Evaluation of the structural model or inner model is carried out to ensure that the structural model built is accurate. Testing can be done by calculating the value of $R$ square and predictive relevance (Q2). The significance of the estimated parameters can be used to see the relationship between variables in the study. Hypothesis test, made by looking at the value of Path Coefficients in Table 5.

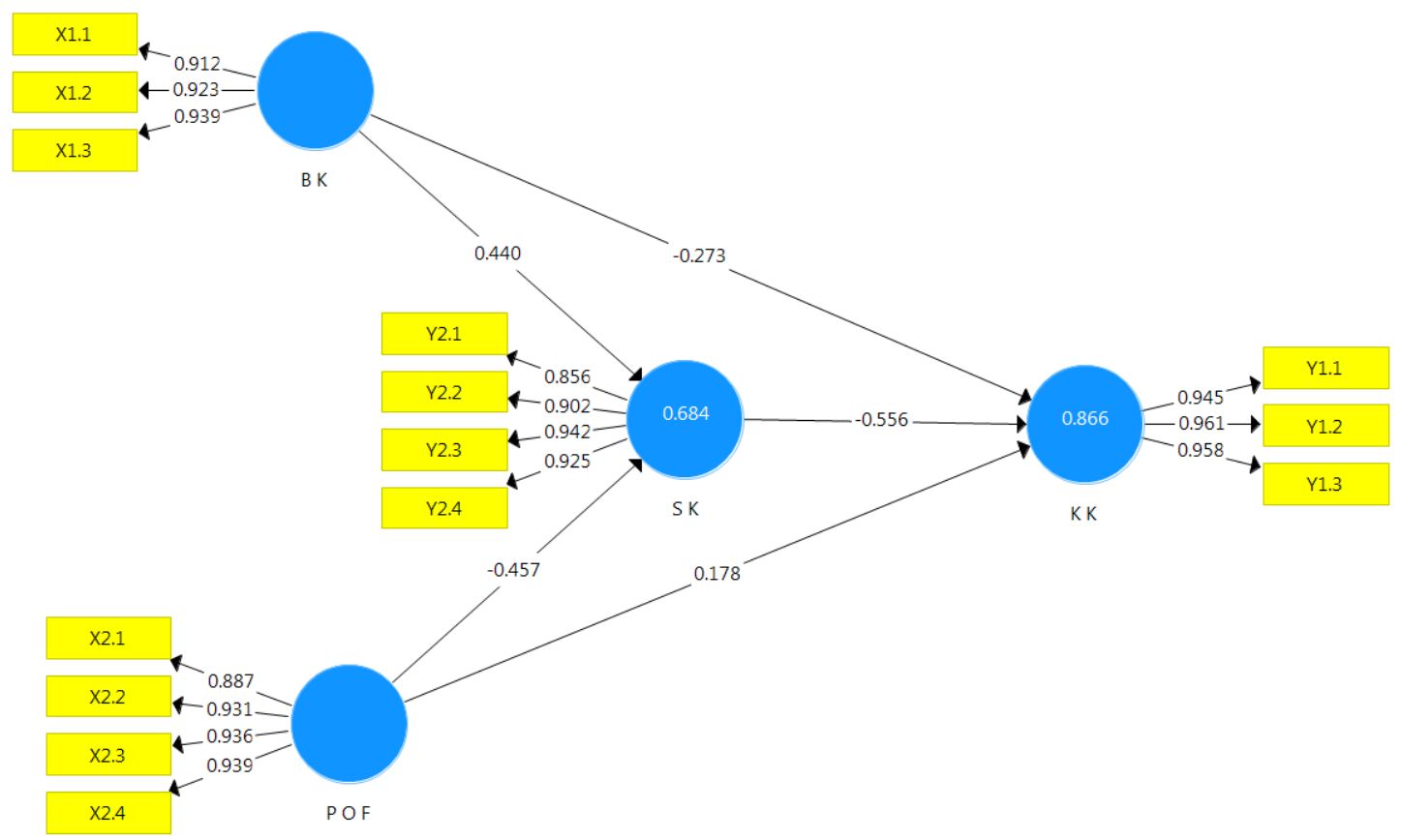

Figure 1 - Model Structural

In Table 4, the job satisfaction variable has an $R$-square value of 0.866 , which means that 86.6 percent of the work satisfaction variance can be explained by workload, personorganization fit, and work stress variables, while the rest is explained by other variables outside the research model. The work stress variable has an $R$-square value of 0.702 , meaning that 70.2 percent of the work stress variance can be explained by workload variables and person-organization fit.

Table 4 - Value of R Square

\begin{tabular}{ll}
\hline Variable & R Square \\
\hline Job Satisfaction $(\mathrm{Y} 1)$ & 0.866 \\
Job Stress (Y2) & 0.702 \\
\hline
\end{tabular}

Based on the value of $R 2$, can be calculated as relevance predictive value (Q2), with interpretation when $Q 2$ is greater than 0 , then the model can be said to be good and be able to explain the phenomenon of Job Satisfaction. The predictive relevance value can be calculated as follows:

$$
Q 2=1-(1-R 12)(1-R 22)=0.958
$$


The results show the value of $Q 2(0.958)$ is greater than 0 , so that it can be interpreted that the model is good because of the relevant predictive value, which amounted to 95, 8 percent. This shows that variations in the job satisfaction variable can be explained by the variables used, namely workload, person-organization fit, and work stress, while the remaining 4.5 percent is explained by other variables outside the model. $\mathrm{P}$ Value hypothesis, made by looking at the value of the path coefficients are presented in Table 5 Testing the hypothesis is evaluated to see the value of t-statistic, and the $p$-value. In the condition that the t-statistic is greater than the t-table (1.96), and the p-value is below 0.05 , the research hypothesis can be accepted. In table 5 , it is known that the effect of workload (X1) on job satisfaction ( $Y 1$ ) has a t-statistic value of 2,564 and a p-value of 0.011 , so there is a negative and significant effect between workload (X1) on job satisfaction (Y1), so $\mathrm{H} 1$ is accepted.

Table 5 - Path Coefficients

\begin{tabular}{lllll}
\hline Variable & Path Coefficients & T Statistics $(\mid$ O / STDEV $\mid)$ & P Values & Information \\
\hline BK $->$ KK & -0.273 & 2,564 & 0.011 & H1 accepted \\
BK $->$ SK & 0.364 & 2,364 & 0.018 & H2 accepted \\
POF -> KK & 0.224 & 2,444 & 0.015 & H3 is accepted \\
POF - > SK & $-0,534$ & 3,439 & 0.001 & H4 accepted \\
SK $>$ KK & $-0,534$ & 5,909 & 0,000 & H5 accepted \\
\hline
\end{tabular}

Person-organization influence fit (X2) on job satisfaction (Y1) t-statistic has a value of 2,444 and a p-value of 0.015 , there is a positive and significant influence between personorganization fit (X2) against complacency work (Y1), then $\mathrm{H} 2$ is accepted. Next, the effect of job stress (Y2) on job satisfaction (Y1) has a t-statistic value of 5,909 and a p-value of 0,000, so there is a negative and significant influence between job stress (Y2) on job satisfaction (Y1), so that $\mathrm{H} 3$ is accepted. Furthermore, the workload (X1) to work stress (Y2) has a value of t-statistic of 2, 364 and a p-value of 0.018 , there is a positive and significant influence between workload (X1) to work stress (Y2), so H4 is accepted. Next, the effect of personorganization fit (X2) on work stress (Y2) has a value of t-statistic of 3, 439 and a p-value of 0.001 , then there is a negative and significant influence between person-organization fit (X2) and job stress (Y2), then H5 is accepted.

Table 6 - VAF calculation

\begin{tabular}{|c|c|}
\hline \multicolumn{2}{|l|}{ Indirect Influence } \\
\hline Workload $\rightarrow$ Job Stress $\rightarrow$ Job Satisfaction & -0.194 \\
\hline Person Organization Fit $\rightarrow$ Job Stress $\rightarrow$ Job Satisfaction & 0.285 \\
\hline \multicolumn{2}{|l|}{ Direct Influence } \\
\hline Workload $\rightarrow$ Job Satisfaction & -0.273 \\
\hline Person Organization Fit - Job Satisfaction & 0,224 \\
\hline Job Stress $\rightarrow$ Job Satisfaction & -0.534 \\
\hline Workload $\rightarrow$ Work Stress & 0,364 \\
\hline Person Organization Fit $\rightarrow$ Job Stress & $-0,534$ \\
\hline \multicolumn{2}{|l|}{ Total Effect } \\
\hline Workload, Job Stress, Job Satisfaction $(-0,194+-0,273)$ & -0.467 \\
\hline Person Organization Fit, Job Stress, Job Satisfaction $(0.285+0.224)$ & 0.509 \\
\hline \multicolumn{2}{|l|}{ VAF = Indirect Effect / Total Effect } \\
\hline 1. Workload $=>$ To work $p=(-0,194 /-0,467)$ & 0.415 \\
\hline 2.Person Organization Fit $=>$ work $=(0.285 / 0.509)$ & 0.560 \\
\hline
\end{tabular}

Based on the calculations in Table 6 , the stress of work as a variable VAF mediation has a value of $0,415(41.5 \%)$. So we can conclude work stress me mediation partially relationship workload to job satisfaction. So the hypothesis that occupational stress acts as mediation relationship between workload to job satisfaction can be accepted. Table 6 , also showed that job stress as a mediating variable VAF has a value of 0,560 (56.0\%). It can be concluded that work stresses me mediation partially relationship Person Organization Fit on job satisfaction. So the hypothesis which states that job stress acts as a mediator between Person Organization Fit and job satisfaction can be accepted. 


\section{DISCUSSION OF RESULTS}

Effect of Workload on Job Satisfaction. Hypothesis testing of the effect of workload on job satisfaction in this study shows that workload has a negative and significant effect on job satisfaction. These results are by the first hypothesis $(\mathrm{H} 1)$ which states that workload has a negative and significant effect on job satisfaction. This means that the higher the workload of human resources in a company, the job satisfaction decreases. This is due to the large number of tasks given to reduce employee morale. According to Srimarut \& Mekhum (2020) employees who are given a lot of burdens will find it hard to work because they are not satisfied. Through the three workload indicators in this study, it can be seen that the increase in employee job satisfaction, namely from clear task targets, good working conditions, and appropriate work standards. When employees feel that the targets to be achieved are clear, the employees will work well so that they will get results that make employees feel satisfied. This research is in line with previous research conducted by Sulastriningsih, et al (2018), Bazazan et al (2019), Mansoor, et al (2011), and Rehman et al. (2012) who have proven that workload has a significant negative effect on job satisfaction.

Influence of Person-Organization Fit on Job Satisfaction. Hypothesis testing on the effect of Person-Organization Fit on job satisfaction in this study shows that personorganization Fit has a positive and significant effect on Job Satisfaction. These results are by the second hypothesis $(\mathrm{H} 2)$ which states that person-organization Fit has a positive and significant effect on job satisfaction. This means that the higher the level of compatibility of human resources in a company with the organization or place of work, the job satisfaction will increase. Through the four indicators of person-organization Fit in this study, it can be explained to increase employee satisfaction by having the same values between the organization and employees to achieve organizational goals. Employees can trust the organization and vice versa. Also, the organization must be fair in dealing with employees who are under the auspices of the organization. This research is in line with previous research conducted by Farooquia and Nagendra (2014), which have proven that personorganization Fit has a significant positive effect on job satisfaction.

The Effect of Job Stress on Job Satisfaction. Hypothesis testing of the effect of job stress on job satisfaction in this study shows that Job Stress has a negative and significant effect on Job Satisfaction. These results are by the third hypothesis (H3) which states that job stress has a negative and significant effect on job satisfaction. This means that the higher the stress level of human resources in a company, the lower the Job Satisfaction. Human resources who are not satisfied because they have a high level of stress will be shown by a decrease in performance. Through four indicators of job, stress to increase job satisfaction seen from employee responses. Adjustment response which is the result of individual interaction with their work to external situations of opportunities, constraints, unbalanced demands that cause physical and psychological deviations that affect cognition and emotion, as well as changes in behavior. This study is in line with previous studies conducted by Mansoor, et al (2011) and Wibowo et al. (2015), Khalidi and Wazalify (2013), who have proven that job stress has a significant negative effect on job satisfaction.

Effect of Workload on Work Stress. Hypothesis testing of the effect of workload on work stress in this study shows that workload has a positive and significant effect on work stress. These results are by the fourth hypothesis $(\mathrm{H} 4)$ which states that workload has a positive and significant effect on work stress. This means that the more workload of human resources in a company, the level of work stress will increase. If the number of tasks is not proportional to both physical abilities and skills and available time, it will be a source of stress (Davis \& Newstrom in Supardi, 2007). Through three workload indicators, it can be seen to reduce employee work stress, namely from non-urgent task targets, good working conditions, and appropriate work standards. When employees feel that the targets that must be achieved are clear and they have enough working time, the employees will work well so that it is expected that the stress level is not high. This research is in line with previous research conducted by Mahdadzadeh and Ahmadi (2018), and Qureshi et al (2013) which have proven that workload has a positive and significant effect on work stress. 
The Influence of person-organization Fit on Job Stress. Hypothesis testing of the effect of Person-Organization Fit on work stress in the study shows that Person-organization fit has a negative and significant effect on Job Stress. These results are by the fifth hypothesis (H5) which states that Person-organization fit has a negative and significant effect on work stress. This means that the higher the value equation owned by human resources in a company, the lower the level of work stress. If a match or similarity between individuals and organizations does not occur, it will result in the departure of employees or individuals from the organization (Srimarut \& Mekhum 2020). Through the four indicators of person-organization Fit in this study, it can be explained to reduce the level of work stress by having the same values between the organization and employees to achieve organizational goals. Employees can trust the organization and vice versa. Also, the organization must be fair in dealing with employees who are under the auspices of the organization. Employees and organizations must share the same values of honesty. This research is in line with previous research conducted by Astakhova and Porter (2015), Kim et al. (2013), Jutras \& Mathieu (201 6), and Autry and Wheeler (2005) have proven that person-organization fit has a significant negative effect on job stress.

Job Stress Mediates the Effect of Workload on Job Satisfaction. The work stress mediation test was analyzed by calculating the VAF of work stress as a mediator of workload on job satisfaction. The results of the analysis show that work stress plays a role as partial mediation, meaning that workload can affect job satisfaction directly or indirectly through job stress. Suparlan and Winarti (2020) in his research found that work stress acts as a partial mediation, it can be interpreted that workload can influence job satisfaction directly or indirectly through work stress as a mediating variable. This shows that the decrease in work stress will be a good bridge for the relationship between workload and employee job satisfaction.

Job Stress Mediates the Effect of Person Organization Fit on Job Satisfaction. Testing the mediating role of work stress is analyzed by calculating the VAF of job stress as a mediator for person-organization fit on job satisfaction. The results of the analysis show that job stress plays a role as partial mediation, meaning that person-organization fit can affect job satisfaction directly or indirectly. Chen and Cary (2019) in their research suggest that work stress plays a role as partial mediation, it can be interpreted that person-organization fit can affect job satisfaction directly or indirectly through job stress as a mediating variable.

\section{CONCLUSION}

All hypotheses in this study can be accepted. Workload has a significant negative effect on Job Satisfaction. The more high- workload that employees, the employee will have the job satisfaction level is getting low. Person-Organization Fit has a positive and significant effect on Job Satisfaction. The more aligned the value that employees with values organization then job satisfaction will be further increased. Job Stress has a significant negative effect on Job Satisfaction. Workload has a positive and significant effect on work stress. The more high-workload perceived by the employee, the employee will have high levels of job stress are increasingly high. However, person-organization Fit has a negative and significant effect on job stress. The more aligned the values that employees have with the values of the organization, the more stress the employee's work will tend to decrease. Furthermore, workload and person organizational fit have a direct effect on job satisfaction and have an indirect effect on job satisfaction through job stress. This research implies that it is necessary to have a person organizational fit and control workloads so that employee work stress can decrease so that employees feel higher job satisfaction in the workplace.

\section{REFERENCES}

1. Al Khalidi, D., \& Wazaify, M. (2013). Assessment of pharmacists' job satisfaction and job related stress in Amman. International journal of clinical pharmacy, 35(5), 821-828. 
2. Al-Mohannadi, A., \& Capel, S. (2007). Stress in physical education teachers in Qatar. Social Psychology of Education, 10(1), 55-75.

3. Amarneh, S., \& Muthuveloo, R. (2020). Human resource management practices and person-organization fit towards nurses' job satisfaction. Management Science Letters, 10(14), 3197-3206.

4. Astakhova, M. N., \& Porter, G. (2015). Understanding the work passion-performance relationship: The mediating role of organizational identification and moderating role of fit at work. Human Relations, 68(8), 1315-1346.

5. Autry, C. W., \& Wheeler, A. R. (2005). Post-hire human resource management practices and person-organization fit: A study of blue-collar employees. Journal of Managerial Issues, 58-75.

6. Bazazan, A., Dianat, I., Bahrampour, S., Talebian, A., Zandi, H., Sharafkhaneh, A., \& Maleki-Ghahfarokhi, A. (2019). Association of musculoskeletal disorders and workload with work schedule and job satisfaction among emergency nurses. International emergency nursing, 44, 8-13.

7. Charless, S.A. 2005. Person-Job Fit versus person-Organization Fit as Predictors of Organizational attraction and Job acceptance intentions: A Longitudinal Study. Journal of Occupational and Organizational Psychology, 78, 411-429

8. Chen, P., Sparrow, P., \& Cooper, C. (2016). The relationship between personorganization fit and job satisfaction. Journal of Managerial Psychology, 31(5), 946-959.

9. Deng, X., Liu, X., \& Fang, R. (2020). Evaluation of the correlation between job stress and sleep quality in community nurses. Medicine, 99(4).

10. Farooqui, M. S., \& Nagendra, A. (2014). The impact of person organization fit on job satisfaction and performance of the employees. Procedia economics and Finance, 11(14), 122-129.

11. Hans, A., Mubeen, S. A., Khan, S., \& Al Saadi, A. S. M. (2014). A study on work stress and job satisfaction among headmasters: A case study of bilingual schools in Sultanate of Oman-Muscat. Journal of Sociological Research, 5(1), 40-46

12. Inegbedion, H., Inegbedion, E., Peter, A., \& Harry, L. (2020). Perception of workload balance and employee job satisfaction in work organisations. Heliyon, 6(1), e03160.

13. Iqbal, M., \& Waseem, M. A. (2012). Impact of job stress on job satisfaction among air traffic controllers of civil aviation authority: An empirical study from Pakistan. International journal of human resource studies, 2(2), 53.

14. Jutras, R., \& Mathieu, C. 2016. Person-organization fit relationship with job satisfaction and turnover: The mediating influence of leader-member exchange. Academy of Strategic Management Journal, 15(1), 71-84.

15. Kim, T. Y. Resource Management. Journal of Human Resource Management, 24(19), 3719-3737.Kristof, A.L. 1996. "Person-Organization Fit: An Integrative Review of Its Conceptualizations, Measurement, And Implications", Personnel Psychology. 49, 1-49.

16. Kokoroko, E., \& Sanda, M. A. (2019). Effect of workload on job stress of Ghanaian OPD nurses: The role of coworker support. Safety and health at work, 10(3), 341-346.

17. Liu, B., Liu, J., \& Hu, J. (2010). Person-organization fit, job satisfaction, and turnover intention: An empirical study in the Chinese public sector. Social Behavior and Personality: an international journal, 38(5), 615-625.

18. Madadzadeh, M., Barati, H., \& Ahmadi Asour, A. (2018). The association between workload and job stress among nurses in Vasei hospital, Sabzevar city, Iran, in 2016. Journal of Occupational Health and Epidemiology, 7(2), 83-89.

19. Mansoor, Muhammad., Mohammad Ali Jinnah., Sabtain Fida., Saima Nasir and Zubair Ahmad. 2011. The Impact of Job Stres on Employee Job Satisfaction A Study on Telecommunication Sector of Pakistan. Journal of Business Studies Quarterly, 2(3): 50-56.

20. Netemeyer, R. G., Boles, J. S., McKee, D. O., \& McMurrian, R. (1997). An investigation into the antecedents of organizational citizenship behaviors in a personal selling context. Journal of marketing, 61(3), 85-98. 
21. Parimita, W., Pambudi, W. S., \& Aminah, H. (2017). The Impact of Career Development And Workload Toward Employee Job Satisfaction At Pt Askrindo Jakarta. JRMSI-Jurnal Riset Manajemen Sains Indonesia, 8(1), 39-57.

22. Qureshi, M. I., Iftikhar, M., Abbas, S. G., Hassan, U., Khan, K., \& Zaman, K. (2013). Relationship between job stress, workload, environment and employees turnover intentions: What we know, what should we know. World Applied Sciences Journal, 23(6), 764-770.

23. Rahyuda, I Ketut. 2017. Metode Penelitian Bisnis Edisi Revisi 2017. Denpasar: Udayana University Press.

24. Rehman, R. R., \& Waheed, A. (2012). Work-Family Conflict and Organizational Commitment: Study of Faculty Members in Pakistani Universities. Pakistan Journal of Social \& Clinical Psychology, 9(2).

25. Rochmah, T. N., \& Tunggareni, H. S. (2013). Job Satisfaction and Performance of Nurse Based on Workload in Bhayangkara Hospital Lumajang. Jurnal Administrasi Kesehatan Indonesia, 1(3), 3826.

26. Shurbagi, A. M. A. 2014. The relationship between transformational leadership and organizational commitment in National Oil Corporation of Libya. 3rd International of Humanities, Economics and Geography. 3(7): 85- 91.

27. Srimarut, T., \& Mekhum, W. (2020). The Influence of Workload and Co-Worker Attitude on Job Satisfaction among Employees of Pharmaceutical Industry in Bangkok, Thailand: The Mediating Role of Training. Systematic Reviews in Pharmacy, 11(2), 603-611.

28. Suparlan, S., \& Winarti, R. (2020). The Relationship of Workload with Stress Levels in Nurses. Jurnal Keperawatan, 12(4), 993-1000.

29. Taylor, S. E. (1991). Health Psychology 2nd Edition. University of California, Los Angeles: MGraw-Hill.

30. Velnampy, T., \& Aravinthan, S. A. (2013). Occupational stress and organizational commitment in private banks: A Sri Lankan experience.

31. Vignato, J. A., Arends, L., \& Nicholson, A. (2020). Decreasing Nursing Student Workload and Stress: An Innovative Method to Reform Clinical Assignments Across the Curriculum. Nursing Education Perspectives.

32. Weiss, D. J., Dawis, R. V., \& England, G. W. (1967). Manual for the Minnesota satisfaction questionnaire. Minnesota studies in vocational rehabilitation.

33. Wibowo, A., \& Giessen, L. (2015). Absolute and relative power gains among state agencies in forest-related land use politics: The Ministry of Forestry and its competitors in the REDD+ Programme and the One Map Policy in Indonesia. Land Use Policy, 49, 131-141. 